\title{
Rao's score test in spatial econometrics
}

Luc Anselin

Follow this and additional works at: https://researchrepository.wvu.edu/rri_pubs

Part of the Regional Economics Commons

\section{Digital Commons Citation}

Anselin, Luc, "Rao's score test in spatial econometrics" (1997). Regional Research Institute Publications and Working Papers. 163.

https://researchrepository.wvu.edu/rri_pubs/163 


\title{
The Effects of Federal Spending on Earnings Change in Appalachia
}

by

\author{
F. Carson Mencken and James H. Noonan \\ RESEARCH PAPER 9726
}

\author{
Send all comments to: \\ F. Carson Mencken \\ fmencken@wvu.edu \\ Department of Sociology and Anthropology \\ West Virginia University \\ P.O. Box 6326 \\ Morgantown, WV 26506-6326
}

August, 1997

\begin{abstract}
In this paper we investigate the effects of federal spending on earnings change in Appalachian counties during the 1983-88 recovery and 1989-92 recession. Specifically, we explore the effects of federal spending from grants/research, procurement, salary/wages and defense. The analysis controls for key concepts in the human ecology and new urban sociology. The dependent variables are earnings change for each business cycle from a shift-share analysis, which decomposes county earnings change into that from nationally expanding industries and that from nationally declining industries. The analysis shows that federal spending has no effect on earnings change, when it is considered as an aggregate measure. However, when federal spending is reclassified into the four categories, spending for grants/research has a positive effect on both measures of earnings change in the 1983-88 recovery. Moreover, the effects of grants/research spending are dependent upon the education level of the county population. However, education by grants/research interaction effect is specific to nonmetro counties in Appalachia. Implications for future research are discussed.

${ }^{*}$ F. Carson Mencken is an Assistant Professor, Department of Sociology and Anthropology and Faculty Research Associate, Regional Research Institute, West Virginia University.
\end{abstract}


Introduction

The objective of this paper is to analyze the effects of federal spending on socioeconomic performance in nonmetropolitan counties in Appalachia during the 1980s and early 1990s. Analyzing federal spending is an important project for two key reasons. From an academic perspective, it is a point of contention between the new urban sociology and the human ecology, two theoretical perspectives at opposite ends of the agency-structure continuum of macro-level social system growth. New urban sociologists view federal spending as a direct cause of unequal socioeconomic growth. Through changing spending priorities, such as shifts in domestic to defense spending, the federal government has the power to directly invest and divest in local economies. Many human ecologists maintain, however, that the ecological structure of a community (age and condition of roads, sewer systems, population density, etc.) is a more important determinant of socioeconomic change than local differences in federal spending. Second, this question has policy implications in a political environment where balanced budget and deficit reduction take priority over spending programs. This research will inform us as to the consequences of cuts in different areas of federal spending. Additionally, much of the previous research in this area has focused on urban/rural differences in federal spending, and the impact of these differences on the socioeconomic gap between metro and nonmetro communities. This project will make unique contributions to this literature by focusing on nonmetro areas.

\section{Literature Review}

\section{Human Ecology and New Urban Sociology}

The human ecology and the new urban sociology are two theoretical perspectives of macro-social system growth and change, which are at opposite ends of the structure-agency continuum. Human ecology theory maintains that local ecosystem growth is achieved through spatial dominance of primary sustenance functions and diversity of sustenance activities (Poston 1984; Hawley 1986; Irwin and Kasarda 1991; Murdock et al. 1993). Those communities which have dominant and diverse sustenance functions in a spatially linked system of sustenance activities receive greater resource inputs. New resources increase the complexity of an ecosystem, and as more resources are introduced into an ecosystem, the 
need for coordination and integration functions (i.e. jobs) increases (Poston 1984; Hawley 1986; Kasarda and Irwin 1991; Frisbie and Poston 1976; 1978; Murdock et al. 1993; Singelmann et al. 1993; Mencken, 1996; 1997).

Diversity and dominance of sustenance activities can be linked to the ecological structure of social systems. Ecological characteristics of social systems affect the ability of a social system to attract and retain a diversity of jobs in high growth industries (Kasarda and Irwin 1991). Population density introduces higher costs for land and physical limits on social system expansion. Areas with older infrastructures have higher transportation costs due to poor road conditions and poor access, and less reliable public services- both of which make the costs of production rise, and make communities less competitive when attempting to attract new industries (see also Suttles 1984). Areas without interstate transportation access, or access to metropolitan areas are at a disadvantage when recruiting new industries (Rephan and Isserman 1995).

The new urban sociology is a conflict oriented theoretical perspective on local social system growth. Where human ecology views systems of spatial dominance resulting from technological innovations and functional imperatives of market adaptations, the new urban sociology contends that they are the product of social groups pursuing interests (Smith 1995; Gottdiener and Feagin 1988). The new urban sociology is interested in how political economic systems work, how groups acquire and monopolize power, who gains and who loses. One of the key research issues of the new urban sociology is the state disparity hypothesis (Smith 1995: 440-1; Gottdiener and Feagin 1988: 172-74). Federal funding policies create spatial variation in socioeconomic performance. The federal government makes certain locales competitive through direct investments in high growth industries -- particularly military/defense and research/development (Castells 1988; Markusen 1987; 1994).

Much of the previous empirical research on the effects of federal spending on local economic wellbeing has been done by geographers, planners and economists. The primary focus of this research has been on regional variation in federal spending, and how this variation creates regional differences in economic growth. One general theme consistent in this literature is that regional differences in federal spending on infrastructure (water projects, bridges, dams, highways, interstates, etc, ) create regional 
differences in economic growth (Markusen 1994; Glickman and Glasmeier 1989; Malecki and Nijkamp 1988; Rephann and Isserman 1994). Military spending has had an important impact on regional and local economic growth during and since World War II. For example, Nash (1985) shows that the federal government spent 40 billion dollars in the western United States during World War II, creating new jobs in aerospace and electronics manufacturing, and in natural resource extraction industries. New jobs in these industries had multiplier effects in manufacturing supply services, and retail/personal services, leading to even further population growth and urbanization. The federal investments in the local economies in the western United States during the war established western economies (particularly Los Angeles, San Francisco, and Seattle) as the economic pace setters in the post War period.

Others maintain that regional variation in defense spending during the 1970 s and 1980 s affected regional variation in socioeconomic growth during this period (Markusen 1987; 1994; Markusen et al. 1991; Glickman and Glasmeier 1989; Markusen and Carlson 1989; Malecki and Nijkamp 1988; Mehay and Solnick 1990). States in the 'gunbelt' received a disproportionate share of defense contracts and spending (Markusen 1994: 5). Areas that particularly benefitted include Boston (Route 128 corridor), Newport News, VA, Huntsville, AL, Houston and San Antonio TX, Los Angeles, CA; the Silicon Valley region, and Seattle, WA. Additionally, southern and western states held a greater proportion of military bases, received $50 \%$ of all military payroll, and $50 \%$ of all Pentagon research and development funds (Gottdiener 1994: 258).

In sociological research, the effects of government finance on local economic conditions have been primarily the domain of the new urban sociology (see Smith 1995; Gottdiener and Feagin 1988; Gottdiener 1994). One of the key assumptions of the new urban sociology is that the state plays a very important role in affecting the flow of capital (state disparity hypothesis- see Smith 1995: 440-1; Gottdiener and Feagin 1988: 172-74; Gottdiener 1994). The federal government has the power to make substantial economic investments and divestment in communities. Proponents of the state disparity hypothesis from the new urban sociology contend that federal funding policies create spatial variation in economic performance. From the end of World War II through the 1970s, federal spending has favored large cities 
(Castells 1988; Markusen 1987). According to Mollenkopf (1983), since WWII, one-third of all manufacturing jobs created in the high-tech electronics and computer industry sectors (primarily in the suburbs of large cities) have been the direct result of federal defense spending. Los Angeles (CA) county alone received 13.8 billion dollars in defense prime contracts in 1984 , while 124 billion dollars in defense contracts went to firms in metro areas in 1984 (Markusen 1994:6).

Less work has been done on federal spending among nonmetro counties. The work that does exist focuses on how spending changes led to an increase in the socioeconomic gap between metro and nonmetro areas during the 1980s (Falk and Lyson 1993; Singelmann et al 1993). For example, Falk and Lyson (1993) contend that the socio-economic spatial disparities in the 1980 s were created partly by the transfer of dollars from successful nonmetro development programs to defense contracts (see also Castells, 1988; Markusen, 1994). According to Falk and Lyson (1993: 268) over 8 billion dollars were cut from rural development programs, such as FMHA business loans, Economic Development Administration, Community Development Block grants, and over 6 billion in General Revenue Sharing during the 1980s. According to Falk and Lyson (1993), the funding cuts to these programs and the reallocation of these dollars to defense contractors negatively impacted nonmetro economies while creating job growth in the suburbs of large cities. Recent research by Mencken and Singelmann (Forthcoming) supports this claim by showing that federal spending was more important for earnings and income growth in metro communities (compared to nonmetro) throughout the 1980s. In addition to the financial strains created by cuts to rural development programs, Lyson (1989) argues that the funding cuts also removed important federal leadership from such programs.

Other research shows that nonmetro areas benefit, to some extent, from two forces related to federal spending: an aging population and a pattern of nonmetro migration of retired individuals. Nonmetro communities have experienced an increase in net in migration of retirees (Glasgow 1995; Fuguitt and Beale 1992; Glasgow and Beale 1985). These economies have experienced marginal socioeconomic growth due to the expansion of retirement facilities, and an increased demand for health services. Therefore, federal entitlement payments (social security, medicare) have indirectly benefitted the economies of nonmetropolitan areas. However, sociological research on the effects of other federal 
expenditures on socioeconomic growth in nonmetro counties (defense, R\&D, etc) have not been fully investigated.

In addition to federal spending, federal employment can give local communities a competitive advantage during business cycles. Mollenkopf (1983) argues that federal spending has several positive effects on the performance of local economies. First, the federal government creates market demand for certain goods (i.e. procurement), especially defense industry products. Second, the federal government directly or indirectly employs a significant proportion of the civilian labor force. Civilian layoffs during business cycle downturns are less prominent in the public sector, since the demand for government services generally increases during periods of economic strife (unemployment benefits, welfare entitlement, job training, etc). Therefore, areas with a greater concentration of federal employment may perform better during business cycle downturns because of more stable labor markets.

The federal government also serves as a "banker" for local governments and non-profit agencies. Federal dollars indirectly employ individuals in local, state, and non-profit agencies in areas such as education, research, social services, health and housing. Federal spending stabilizes employment in areas where this funding is concentrated, which translates into consistent consumption of goods and services and a stable tax base. Local stability, bolstered by federal spending, creates a situation where investment in ecological competitive factors (such as roads, bridges, other infrastructure and schools) is more feasible, and this gives certain areas a competitive advantage (Kasarda and Irwin 1991).

\section{Appalachia}

Appalachia is chosen as a case study for several reasons. It is a large area encompassing 399 counties in 13 states, with over 20 million people. It is a region which covers parts of the old (Pennsylvania, Ohio, Western New York) and new (Georgia, Alabama, North and South Carolina) industrial belts. It has both an urban and rural population base, and it has areas which are economically well-off and those which are doing poorly (Couto 1994; Maggard 1994; Mencken 1997). Moreover, the economic trends of the last three business cycles have impacted Appalachian counties in ways that are very similar to the rest of the United States (Isserman 1995; Anselin 1995; Mencken 1996). Appalachia is also an interesting case study because it is a region which has had a federal agency devoted to its well- 
being since the 1960 s (Presidents Appalachian Regional Commission). (Appalachia and its subregions can be found in Map 1).

Map 1 about here

A regional analysis may be more appropriate for the research question at hand. Regions, such as Appalachia, the Mississippi Delta, and the Rio Grande Border (just to name a few) have unique cultures and economic histories, or what are often referred to as 'place' qualities that are hard to quantify, but nonetheless exert important influence on current cultural and socioeconomic issues (Szreter 1993; Lervernier 1996; Bishop et al. 1992; Nissan and Carter 1993; Couto 1994). Therefore, socioeconomic research done across regions exposes the analysis to the risk of 'mixing' unique historical context that may not be controlled very well in regression models. However, by focusing on a case study of one region, particularly one that covers as much of the United States as Appalachia (399 counties, 13 states, 20 million people), this problem is minimized, while at the same time a large enough collection of counties is available for a rigorous analysis.

\section{DATA AND ANALYSIS}

The objectives of this paper are to analyze the effects of federal spending on local socioeconomic growth in the 399 Appalachian counties during the 1983-88 business cycle recovery and the 1989-92 recession. The project will disaggregate federal spending into key categories: defense, research and development, salaries/wages and procurement. In the process of pursuing this objective three key issues will be addressed: 1) What effect, if any, federal spending has on socioeconomic growth in nonmetro counties, 2) Does federal spending affect nonmetro counties the same way in recessions and recoveries, and 3) Establish which sources of federal spending had the most impact on socioeconomic growth (defense, R\&D, etc.).

The analysis is separated by business cycles because characteristics of local economies (such as industry structure, the education level of workforce and possibly federal spending) have different effects on socioeconomic growth during business cycles (Singelmann et al., 1993; Kasarda and Inwin 1991; Mencken 1996). The years $1983-92$ are chosen because of data availability. Prior to 1983, detailed federal spending data at the county level are less available. The analysis employs a modified version of 
population growth rate models, where the independent variables are measured at the beginning of the business cycle and used to predict growth in the dependent variables across the business cycles.

Data. The data are taken from a variety of county-level data sources. The data for federal spending are taken from the Consolidated Federal Funds Report. This is a data set containing detailed federal spending reports at the county level from 1983-1992. Other measures used in the analysis are taken from other county-level data sources, such as the County Statistics File (COSTAT), County-City Data Book, County Business Patterns, Regional Economic Information Systems, and Census of Population and Housing.

\section{Dependent variables.}

The dependent variables in the analysis are two measures of employment earnings growth computed from shift-share analysis for each time frame (1983-88; 1989-92). Shift-share analysis (see Loveridge 1995) is appropriate because it disaggregates earnings change into a) change attributable to local industry mix (average growth rate across all industries in county minus national growth rate across all industries); and b) the change attributable to the shift of jobs in declining industries (sum of growth rate in each industry in the county minus national growth rate for those industries). The change due to local industrial mix (share) represents earnings change from nationally growing industries. Thus, a positive share value means that county earnings from industrial mix are greater than the national growth rates for all industries, and represents a quality mix of fast growing industries. The change in earnings due to the shift in employment among nationally declining industries represents earnings change from nationally declining industries, and is often conceptualized as a geographical shift in jobs from one place to another (Loveridge 1995). Thus a positive shift value means that earnings summed over all industries in a county are growing faster in the county than the sum across all such industries nationally. The dependent variables in the regression analysis are shift-share components from beginning and end points of each business cycle (1983-88; 1989-92). Therefore, for each business cycle, I predict the earnings change over that cycle from a county's share of nationally growing industries, and the shift of nationally declining industries.

\section{Independent Variables}


From human ecology, we include several key indicators of ecological structure: Population density, metropolitan status (binary variable-1=yes), adjacent to metropolitan area (1=yes). We also include measures of infrastructure age/condition. First, percent of housing stock built before 1939 is a measure of age of infrastructure. It is a proxy variable, recommended by Kasarda and Irwin (1991) for age of water and sewer systems, roads and telecommunication hardware. Second, we include percent of county population that is black as an ecological measure of infrastructure condition. Areas with a higher percentage black typically have poorer infrastructures. Whether or not the county has an interstate highway in it is also included as a binary variable (1=yes).

From the new urban sociology, we include several measures of business climate: a proxy measures of labor force quality (percentage of adult population 25 years or older with some education beyond high school), and a measure of manufacturing compensation -- earnings per manufacturing employee, which includes wages, pension and other forms of compensation. We also control for Right-toWork status of the county in question. The analysis also controls for the effects of mining dependence and agriculture/forestry dependence, with variables that measure percent of total earnings in a county from each of these sectors. Mining is controlled for because growth in mining earnings were drastically different than national growth rates during several of the previous business cycles. The cyclical nature of oil prices caused drastic fluctuations in the demand for coal. Mining-dependent regions in Appalachia experienced employment losses in the mid/late $1980 \mathrm{~s}$, after the price of crude oil declined to under $\$ 20.00$ a barrel, creating less demand for coal (Couto 1994). In addition, the implementation of newer technologies led to the displacement of a significant proportion of the workforce (Maggard 1994). Agriculture and forestry had significantly different growth rates as well (see Couto 1994). Many agricultural goods are inelastic goods, thus the demand for such goods does not change dramatically during economic downturns.

Independent variables are measured at or near the beginning of the respective business cycles. For the earnings change between 1989-1992, the variables are measured near 1989/1990. ${ }^{1}$ For the

\footnotetext{
'Some measures of ecological structure are measured only during Census years $(1980,1990)$. However, this should not create a problem, structural variables do not change much from year to year.
} 
1983-88 model, some measures from 1000 must be used (education, population measures, etc). These variables are not available for non-Census years (such as 1983). The analysis also includes lag terms. For the 1983-88 model, the share and shift factors measures from the 1980-82 model are used as lag effect variables. For the 1989-92 model, the 1983-88 share and shift variables are used as lag predictors.

\section{Federal Spending Measures.}

The analysis empioys four measures of federal spending, each representing a major category of federal spending: Defense (including defense procurement, salaries and wages to military and civilian personnel); salaries and wages (non defense); procurement (non-defense); and grants/research. Each of these measures is computed for 1983 and 1989 on a per capita basis. ${ }^{2}$ In addition, we examine the trends in these categories for each of the years between 1983 and 1992 . For the trend analysis, we first convert nominal dollars in each year (i.e. total defense spending 1983) to real 1993 dollars (i.e. the value of 1983 dollars in 1993), benchmarked to the Consumer Price Index over the time period in question.

In the second stage of the analysis, we predict the effects of government spending programs on the earnings change in Appalachian counties due to the county's share of nationally expanding industries, and the county's share of nationally declining industries using OLS analysis. The analysis controls for the effects of human ecology, new urban sociology and other variables (mining, agriculture, forestry, lag effects) outlined above. Most of these measures are taken from Kasarda and Irwin's (1991) model of business cycle of employment growth, a model that attempts to integrate as many measures from the human ecology and the new urban sociology.

\section{Results}

Figures 1 and 2 show the trends in per capita federal spending (in 1993 dollars) for all categories combined, and the four major categories separately. In Appalachian metro counties, the trend is relatively static. There is a slight peak in total federal spending in 1986, which covaries with the trend in per capita level of procurement spending. Not surprisingly, federal spending per capita is higher in all years among

? Data on county population for non census years are taken from county population estimates provided by the BEA via the Regional Economic Information Systems. 
metro counties. Among nonmetro counties, the trend is more dynamic from year-to-year. This trend is heavily influenced by the trends in per capita procurement spending. Defense spending, while consistently lower in nonmetro Appalachia, is relatively stable across time. The same finding applies to salaries and wages. Grants/research spending fell-off between 1983-1985, but remains relatively stable after that period.

Figures 1 and 2 about here

We also investigated to what extent the trends in nonmetro Appalachia could stem from population changes. Couto (1994) maintains that economic trends during the 1980s affected population changes among nonmetro counties during this period. There is a possibility that the trends in Figure 2 result from changes in nonmetro population, rather than nonmetro federal spending. Figures 3 and 4 present data that show federal spending (not per capita) and population for nonmetro counties during this period. These two figures show that population is relatively stable during this time period, but that federal spending in 1993 dollars is variable, with procurement being the major category of change.

Figures 3 and 4 about here

Of these four categories, defense spending per capita is greater in metro counties for the period in question, with the exception of 1991 and 1992, when procurement spending is higher. Procurement is second in metro counties, followed by salaries/wages and grants/research. For nonmetro counties, the patterns are more volatile. Procurement spending and defense spending are greater than salaries/wages and grants/research spending. However, procurement spending is higher than all other categories in 1984, 1987, 1990, 1991 and 1992. Yet procurement spending is lower than the other categories in 1985. In the regression analysis, we examine to what extent variations across counties in federal spending affect the earnings change in the county for the period in question.

\section{Regression Results}

We estimate several additive and nonadditive regression analyses in the process of exploring the effects of federal spending on earnings change. We first estimate the effects of federal spending when all four categories are combined, and the effects of federal spending when all four categories are combined by metro and nonmetro counties. We then examine the relative effects of each of the four categories, for 
all Appalachian counties, and by metro/nonmetro counties.

Table 1 presents the analysis for all four categories combined. This analysis shows that when federal spending is treated as one category, per capita federal spending has no significant effect on earnings change from nationally expanding nor nationally declining industries in Appalachia during either of the last two business cycles. The variables that are important are measures of education and industry structure, when earnings change from nationally expanding industries is in question, and industry structure and ecological structure when earnings change from nationally declining industries is in question. In other research, Mencken and Singelmann (Forthcoming) document an interaction effect for federal spending by metro/nonmetro areas. ${ }^{3}$ We tested for this effect in Appalachia, and the results are presented in Table 2. The interaction analysis shows that the effects of federal spending are not dependent upon metro/nonmetro status in Appalachia. When federal spending is considered as the sum of the four spending categories, it has no effect on earnings change among Appalachian counties during business cycles since the early 1980 s.

We further tested the relative effects of the four federal spending categories. Table 3 presents the results when federal spending is disaggregated into the four categories (defense, procurement, salary/wages, grants/research). ${ }^{4}$ The analysis shows that once these effects are disaggregated, federal spending has some effect on earnings change during the $1983-88$ recovery. When earnings change from share of nationally expanding industries is considered, grant/research funding per capita has a positive effect on earnings change. This is an expected finding, research and development spending should stimulate growth in emerging industries. However, defense spending has a negative effect on earnings change from nationally declining industries, and this is a time period when national defense budgets were increasing (Markusen 1994; Falk and Lyson 1993). However, the trend analysis shows that defense spending in Appalachian counties remained relatively stable throughout the 1980 s. What this analysis is

\footnotetext{
${ }^{3}$ We used Commuter Zones rather than counties as the unit of analysis in that paper (Mencken and Singelmann Forthcoming).

4 We examined correlations among these four measures, for both years and among metro and nonmetro counties separately. We did not detect correlations that would indicate problems with multicollinearity among these four measures.
} 
probably showing is the Appalachian effect of military spending. According to Couto (1994), Appalachia is removed from the "gunbelt," with no real hub of defense enterprises (with the exception of Huntsville, Alabama). What this analysis shows is that defense spending, which is said to create high growth jobs in certain locales (Markusen 1994), did not create these types of jobs in Appalachia, to the extent that federal spending from grants/research did.

When earnings change from nationally declining industries is considered, grants/research spending also has a positive effect. This is an unanticipated finding, but could stem from the aggregate manner in which grants/research is measured. This variable includes economic development grant money, which may be going into counties that are most successful at 'smokestack chasing,' or attracting industries that are in decline. Further disaggregating this measure into more detailed spending categories may provide different results.

In addition, per capita salaries and wages have a negative effect on earnings growth in nationally declining industries. This finding is expected, since the federal government employs a disproportionately higher percentage of professional/managerial workers, and the federal government is an industry sector in which salary schedules typically grow at the national inflation rate. Therefore, to the extent that salaries/wages measure concentration of federal employees, you would expect per capita spending on federal salaries/wages to have a negative effect on earnings change from nationally declining industries.

For metro counties (Table 4), the analysis shows that defense spending has a negative effect on earnings change from nationally expanding industries during the $1983-88$ recovery. There appear to be no benefits of defense spending in Appalachian counties. None of the other federal spending measures has a significant effect on earnings change, and this includes grant/research spending. Table 5 presents the results for nonmetro counties. This measure has a positive effect on both earnings change measures during the $1983-88$ recovery in nonmetro counties. This finding suggest that there may be an interaction effect between grant/research spending and metro/nonmetro status. However, we estimated a model (not reported) with an interaction term (metro by grant/research) which did not test significant in either the 1983-88 recovery, nor 1989-92 recession. However, the effects of grant/research in that model are significant, and show that grant/research has a significant effect in nonmetro counties, and an effect not 
significantly different in metro counties. This may imply that the non effect of grant/research in metro counties (see Table 4) was a result of the small sample size for this regression model $(n=109)$. Moreover, this positive effect materialized for both earnings change from nationally expanding industries, and from earnings change from nationally declining industries. No interactions were detected for the 1989-92 period.

Tables 3,4 and 5 about here

The previous regression equations show that the education level of the county is a key determinant of earnings growth during both business cycles, particularly for earnings in nationally expanding industries. In the last set of regression equations we test to what extent the effects of education are related to the effects of federal spending. Some argue that the effects of education are that a better educated workforce helps attract jobs, while others suggest that job development increases better educated in-migrants into a community (Kasarda and Irwin 1991; Singelmann et al. 1993; Bartik 1993). Since education has strong positive effects in all models of earnings growth in nationally expanding industries, we test to what extent the effects of grants/research spending are dependent upon the education level of the workforce, and vice versa. It could be that grantiresearch spending creates jobs for better educated workers, and that without this spending, the effects of education would be diminished.

The final analyses are presented in Tables 6 and 7. These analyses for all counties in Appalachia show that models show that education level of the county and grant/research spending are interdependent, when earnings from nationally expanding industries during the 1983-88 recovery are considered. The overall model suggests that the effects of federal spending on grants/research are dependent upon the level of education. The interaction term is positive and significant. As education increases, the effects of grant/research spending increase, as well. However, the effects of education, net of the interaction effect, are positive $(b=419)$ and significant. Therefore, even when the level of grant/research spending are set to zero, education still has a positive effect on earnings change from nationally expanding industries. However, the net effect of grant/research spending is negative, and significant. Therefore, based on our regression models, if the county has a population that has no adults with a greater than high school education, grant/research spending has a negative effect on earnings 
change from nationally expanding industries. The interaction term for earnings change from nationally declining industries between $1983-88$ is not significant. Moreover, no interaction effects materialize in either of the 1989-92 recession models.

The final analysis examines this education by grant/research interaction effect within the context of metro/nonmetro status. The analysis presented in Table 7 shows that the interaction effect is pertinent to nonmetro counties for the 1983-88 recovery. However, there are no effects for the 1989-92 recession. For metro counties, the analysis shows no significant interactions. However, the standardized coefficients suggest that there could be some real problems with multicollinearity with these models (both 1983-88 and 1989-92). However, we conducted a LaGrange-multiplier F-test for increment to R-square, and find that the addition of the interaction terms to the metro county analysis did not significantly improve the fit of the model.

\section{Discussion}

This is a preliminary analysis of a pertinent research and policy question. Our objectives were to assess the effects of federal spending, and spending from general categories on earnings growth in Appalachian counties during recent business cycles. Much of the past research on federal spending has focused on defense spending, or on the socioeconomic consequences of spatial retirement patterns. Our analysis is designed to estimate the effects of spending in general categories, not related exclusively to defense. The analysis shows some interesting but preliminary trends. First, it may not be wise to measure federal spending in the aggregate. Different federal programs have different audiences and intended outcomes. This analysis shows different results when different categories of spending are considered. Specifically, this analysis shows that federal spending on grants and research was more important for earnings growth during the 1983-88 recovery.

In addition to the program in question, the analysis also intimates that the actual dollar amount may not be as important as what the money is intended for. Spending for procurement is the largest category of spending (in 1993 dollars) of the four examined. However, procurement has no effect on either of the earnings change measures, for either of the business cycles in question. However, estimating the effects of procurement with these growth models may not be the most productive method. 
Procurement spending is rather volatile from year-to-year (see Figures 1 and 2). However, defense and salary/wages are categories where federal spending per capita was higher than federal spending on grants/research. However, neither of these categories has any positive effect on the earnings growth measures. Again, it is not necessarily the volume of spending, but what the money is intended for.

The findings for defense spending are rather counter-intuitive to our conceptions about defense spending, particularly during the 1980 s. There are a plethora of studies that herald or lament (depending upon your political perspective) the effects of defense spending during this time period (see Markusen 1994 for best review, but also Nash 1985; Falk and Lyson 1993; 1988; Gottdiener 1994; Mollenkopf 1983). However, these results show little fluctuation in real defense spending, and no positive effects of this spending in any of the regression models. However, this may reflect a regional effect, and not a contradiction to the defense spending literature. Couto (1994) points out that the Appalachian region is relatively removed from the 'gunbelt,' or the term given to those regions which receive a substantial proportion of defense contracts. While Appalachia receives its share of defense funds-- metro counties received over 5001993 dollars per capita for each year in question, nonmetro counties over 200 dollars--it may be substantially less than other places. In addition, the lack of effects for defense spending in this analysis (in contrast to much of the established literature) may serve to underscore the point about the variation in types of federal spending. While one might make that argument that defense spending is good for the economy because it creates quality jobs, and Mollenkopf (1983) shows that about 1/3 of high tech manufacturing jobs can be traced to defense spending, this analysis implies that it is only certain types of defense spending that will stimulate real earnings growth.

Another implication of this analysis concerns the effects of federal spending during national business cycles. The trend analysis of per capita spending in real 1993 dollars shows that federal spending, particularly in metro areas and non procurement spending in nonmetro areas remained relatively stable during the 1980 s and early 1990 s. Theoretically, we would expect federal spending to exert greater relative effects during business cycle downturns. During downturns, social systems receive less resource inputs, due to an overall contraction in the niche from which all communities draw sustenance (i.e. national economy). Therefore, we would expect public sector factors to assume a more 
prominent role, especially given the relative stability of federal spending during this time period (see Figures 1 and 2). To our chagrin, the analysis fails to show any effects of federal spending during the recession, either as an aggregate measure or as general categories. However, it may be premature to conclude that federal spending only matters when times are good. Other analyses which focus on other regions of the country during these and other business cycles are needed.

This analysis focused solely on Appalachia. We stated earlier that a regional analysis is very appropriate to the question at hand. Some regions have unique histories and cultures which affect socioeconomic issues, but that are hard to quantify, measure and control in regression analysis. Moreover, Appalachia makes for an interesting case study because it is a region that has had a federal agency devoted to improving the quality of life for its citizens (President's Appalachian Regional Commission). There are two strains of future analysis needed. One is a direct assessment of the effects of ARC spending. This paper analyzed grants/research spending, which included money from the ARC. These models need to be reanalyzed focusing exclusively on ARC spending. Second, analyses need to be done on other regions and compared to Appalachia. This will help better document which effects are generalizable to places, and which are unique to Appalachia.

Theoretically, federal spending has been the domain of the new urban sociology. Other perspectives of social system change have considered federal spending somewhat of an after-thought, related to industry structure. This analysis points out that federal spending can have unique effects. This analysis has implications for both the new urban sociology and the human ecology. The new urban sociology has considered federal spending as a key variable (state disparity hypothesis), but the focus has been on defense spending, and/or on urban places (Logan and Molotch 1987). This analysis shows that the role of the federal government in creating spatial inequalities needs more focus than defense spending. More importantly, the political economy of non-defense spending (i.e. the place politics of attracting more grants/research dollars to an area) need exploration. The human ecology does not seriously consider the role that federal spending plays in affecting system size and complexity. This is a shame, because the state can play an active role in affecting key ecological dimensions of communities. For example, state funding of transportation and communication technology development can have 
important impacts on social system size and complexity, to the extent that such funding increases the transportation and communication technology of a system. Moreover, federal spending on infrastructure can directly affect the ecological structure of communities; and subsequently social system size and complexity to the extent that infrastructure development helps to attract new jobs. Ecological models (both conceptual and empirical) should attempt to better integrate the actions of the federal government.

Probably the most intriguing and important finding of this research is the interaction effect between federal spending on grants/research and the education level of the workforce for earnings change in nonmetropolitan Appalachian counties. This finding shows that education is an important predictor of earnings change from nationally expanding industries in nonmetro counties. However, for each additional dollar of federal spending on grants/research, this effect is 'intensified,' leading to even greater returns to the education level of the adult population. We believe that further research is needed on the true nature of this relationship. We anticipate that in nonmetro areas, federal spending and the education level of the adult population are linked in a symbiotic relationship. Grants and research employ professionals at universities, research centers and institutes. The grant and research money draws professionals to these nonmetro places. This analysis shows that this symbiotic relationship is functional for these areas, providing employment opportunities that lead to the development of high growth industries, at least during economic recoveries. We believe that to the extent that a well-educated workforce is a draw for certain industries (particularly high tech and producer service industries), this symbiotic relationship could lead to quasi-multiplier effects, or the addition of jobs in a community that are to some extent independent of the symbiotic relationship discussed above, but still dependent upon that relationship to the extent that it helped draw those jobs to the community in the first place. More research is needed on a) to what extent the hypothesized symbiotic relationship between grants/research and the education level of the workforce leads to further employment growth not directly related to the grants; and b) to what extent cuts in federal grants/research would negatively impact nonmetro communities, both directly through the loss of grants and research funds, and subsequently through the loss of better educated workers, and with them the communities ability to attract the quasi-multiplier effect jobs. Finally, this analysis focuses on earnings growth computed from a shift-share analysis, which 
decomposes earnings change into nationally expanding and nationally declining industries. More research on the effects of federal spending on other dependent variables is needed. This analysis shows some benefits of federal spending on earnings change. There are other place characteristics, such as household poverty, earnings inequality, median family household, which need to be investigated to assess the potential effects of future federal spending changes on these indicators of social well-being. 
References

Anselin, Luc. 1995. "Spatial Patterns in Appalachian Growth and Development: A Report to the Appalachian Regional Commission." Working Paper 9512, Regional Research Institute, West Virginia University, Morgantown, WV.

Bartik, Timothy. 1993. "Who Benefits from Local Job Growth: Migrants or the Original Residents?" Regional Studies September: 297-311.

Bishop, John A., John P. Formby, and Paul Thistie. 1991. "Changes in the US Earnings Distributions in the 1980s." Applied Economics 23: 425-434.

Castells, Manuel. 1988 "High Technology and Urban Dynamics in the United States." in M. Dogan and J.D. Kasarda (eds.), The Metropolis Era. Vol. 1. A World of Giant Cities. Beverly Hills: Sage

Couto, Richard A. 1994. An American Challenge. Dubuque, IA: Kendall/Hunt.

Fuguitt, Glenn V. and Calvin Beale. 1993. "The Changing Concentration of the Older Nonmetropolitan Population, 1960-1990." Journal of Gerontology 48:s278-88.

Glasgow, Nina. 1995. "Retirement Migration and the Use of Services in Nonmetropolitan Counties." Rural Sociology 60: 224-243.

Falk, William and Thomas Lyson. 1988 High Tech, Low Tech, No Tech. Albany: SUNY Press.

-.---1993 "Restructuring local labor markets" Pp. 257-278 in J. Singelmann and F.A. Deseran (eds.) Inequalities in Labor Market Areas. Boulder: Westview Press.

Frisbie, W. Parker and Dudiey L. Poston, 1978. "Sustenance Differentiation and Population Redistribution." Social Forces 57:42-56.

---- 1976. "The Structure of Sustenance Organization and Population Change in Nonmetropolitan America." Rural Sociology 41: 354-370.

Glickman, Norman and Amy Glasmeier. 1989. "The International Economy and the American South." in Deindustrialization and Regional Economic Transformation Pp. 60-80. L. Rodwin and H. Sazanami (eds). Boston: Unwin Hyman.

Gottdiener, M and Joe Feagin 1988. "The Paradigm Shift in Urban Sociology." Urban Affairs Quarterly 24: 163-87.

Gottdiener, Mark. 1994. Social Production of Urban Space Austin, TX: Univ. of Texas Press.

Hawley, Amos. 1986. Human Ecology: A Theoretical Essay. Chicago: Univ. Press.

Irwin, Michael D. and John D. Kasarda. 1991. "Air Passenger Linkages and Employment Growth in U.S. Metropolitan Areas." American Sociological Review. 56:524-537.

Isserman, Andrew M. 1995. "The Evolving Appalachian Economy." Research Paper \#9514. Regional Research Institute, Morgantown, WV.

Kasarda, John D. and Micheal D. Irwin. 1991 "National Business Cycles and Community Competition for 
Jobs." Social Forces 69:733-61.

Lervernier, William B. "The Role of Region Specific Institutionalized Cultural Characteristics on Income Inequality in the American South." The Review of Regional Studies 26:301-316.

Logan, John and Harvey Molotch. 1987. Urban Fortunes Berkeley, CA: Univ. of California Press Loveridge, Scott. 1995. "A Practical Approach to Shift-Share Analysis. Journal of the Community Development Society 26: 110-124.

Lyson, Thomas A. 1989. Two Sides of the Sunbelt. New York: Praeger.

Maggard, Sally W. 1994. "From Farm to Coal Camp to Back Office and MCDonald's: Living in the Midst of Appalachia's Latest Transformation." Journal of Appalachian Studies Association 6:14-38.

Malecki, Edward and Peter Nijkamp 1988. "Military Spending and U.S. Defense Spending." Environment and Planning $\mathrm{C} 1: 31-44$.

Markusen, Ann 1994. "American Federalism and Regional Policy." International Regional Science Review. $16: 3-16$.

Markusen, Ann 1987 Regions: The Economics and Politics of Territory. Rowan and Littlefield.

Markusen, Ann and Virginia Carlson. 1989. "Deindustrialization in the American Midwest: Causes and Responses." in Deindustrialization and Regional Economic Transformation Pp 29-59. L. Rodwin and H. Sazanami (eds). Boston: Unwin Hyman.

Mehay, S. and L. Solnick. 1990. "Defense Spending and State Economies." Journal of Regional Science 4: 477-87.

Mencken, F. Carson 1996 "Income and Employment Change in Appalachia during the 1983-88 Business Cycle Recovery: Locating Differential Effects in North, Central and South Appalachia." Journal of Appalachian Studies 2(1): 77-86.

Mencken, F. Carson 1997. "'Regional Differences in Socioeconomic Well-being in Appalachia" Sociological Focus 30: 79-97.

-...-..- and Joachim Singelmann (Forthcoming) "Socioeconomic Performance in Metropolitan and Nonmetropolitan Areas during the 1980s." Sociological Quarterly May 1998.

Mollenkopf, John H. 1983 The Contested City. Princeton University Press.

Murdock, Steve H., Md. Nazrul Hoque, and Kenneth Backman. 1993. "Determinants of 1980-1990 Net Migration in Texas Counties." Rural Sociology 58:190-209.

Nash, Gerald D. 1985. The American West Transformed Bloomington, IN: Indiana Univ. Press.

Nissan, Edward and George Carter. 1993 "Income Inequality Across Regions Over Time." Growth and Change 24: 303-319.

Poston, Dudley L. 1984. "Regional Ecology: A Macroscopic Analysis of Sustenance Organization." Pp. 323-382. in Sociological Human Ecology. Micheal Micklin and Harvey M. Choldin, eds. Boulder, CO: Westview Press

Rephann, Terance, and Andrew Isserman. 1994. "New Highways as Economic Development Tools" 


\section{Regional Science and Urban Economics 24: 723-751.}

Singelmann, Joachim, Forrest A. Deseran, F. Carson Mencken, and Jiang H. Li. 1993. "What Drives Labor Market Growth?" Pp. 125-142 in J. Singelmann and F.A. Deseran (eds.), Inequalities in Labor Market Areas. Westview Press.

Smith, David A. 1995. "The New Urban Sociology Meets the Old: Rereading Some Classical Human Ecology." Urban Affairs Review. 30:432-457.

Suttles, Gerald. 1984. "The Cumulative Texture of Local Urban Culture." American Journal of Sociology 90:283-304.

Szreter, Simon. 1993. "The Intellectual History of the Theory of Demographic Transition." Population and Development Review. 


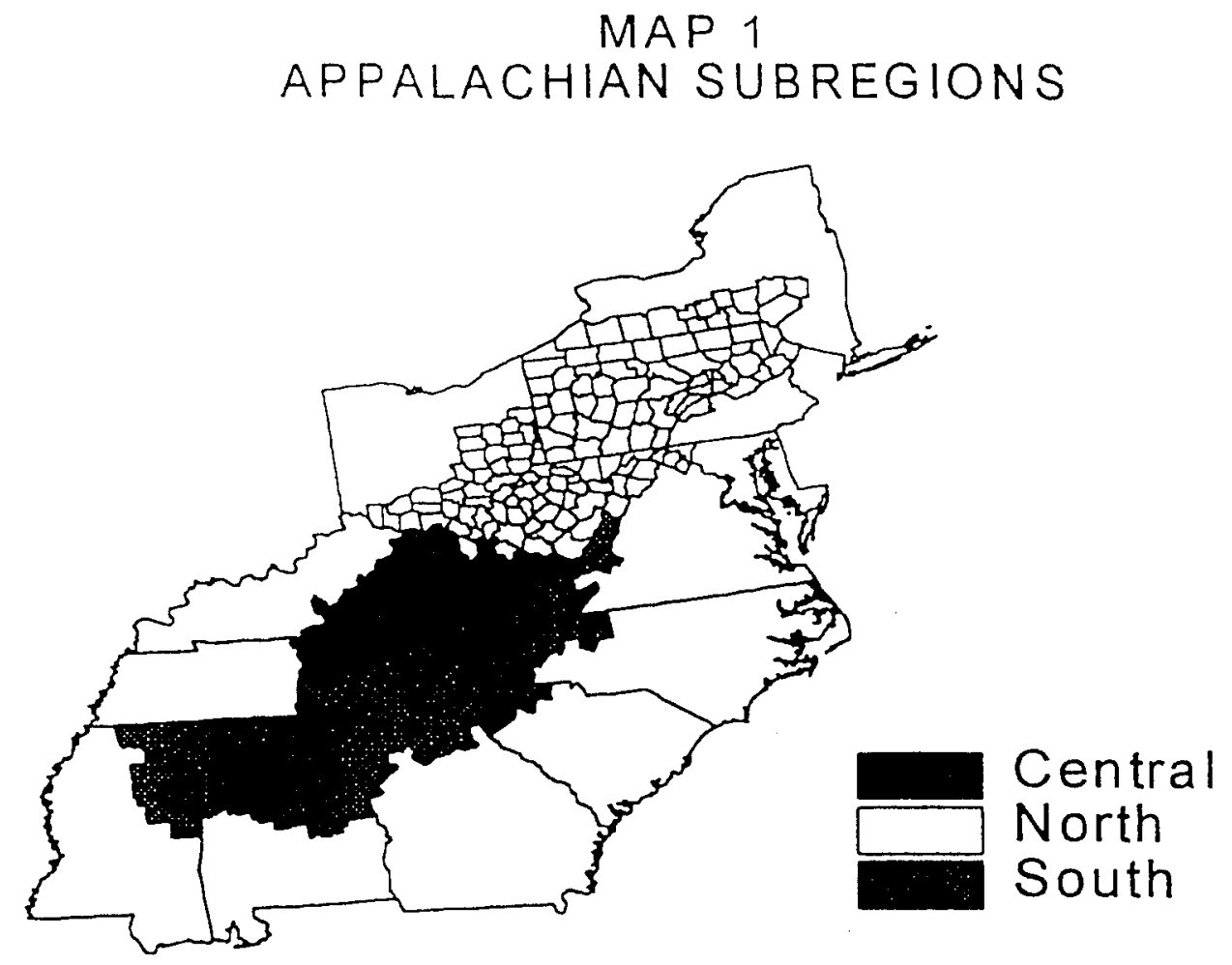




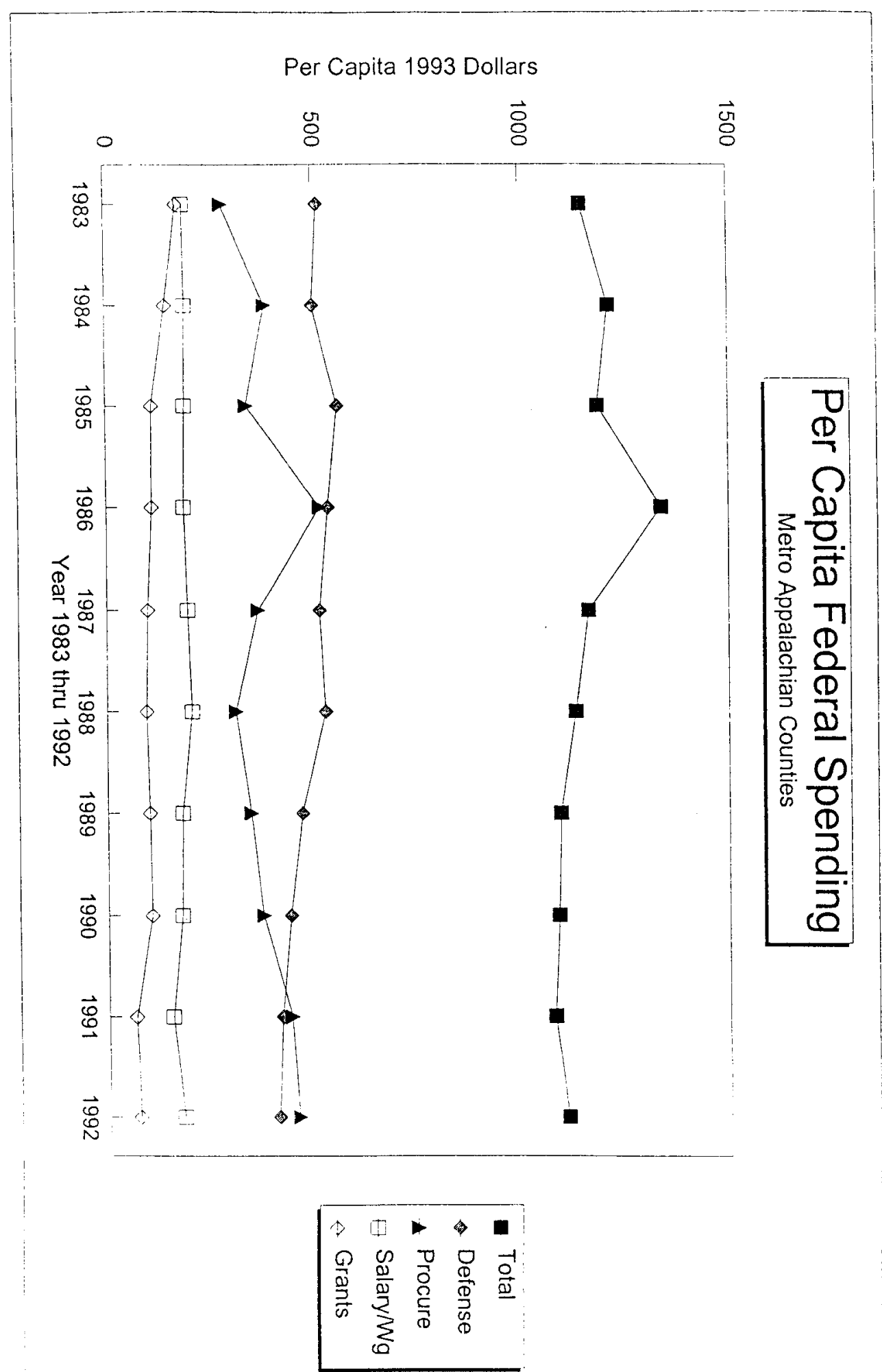

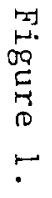




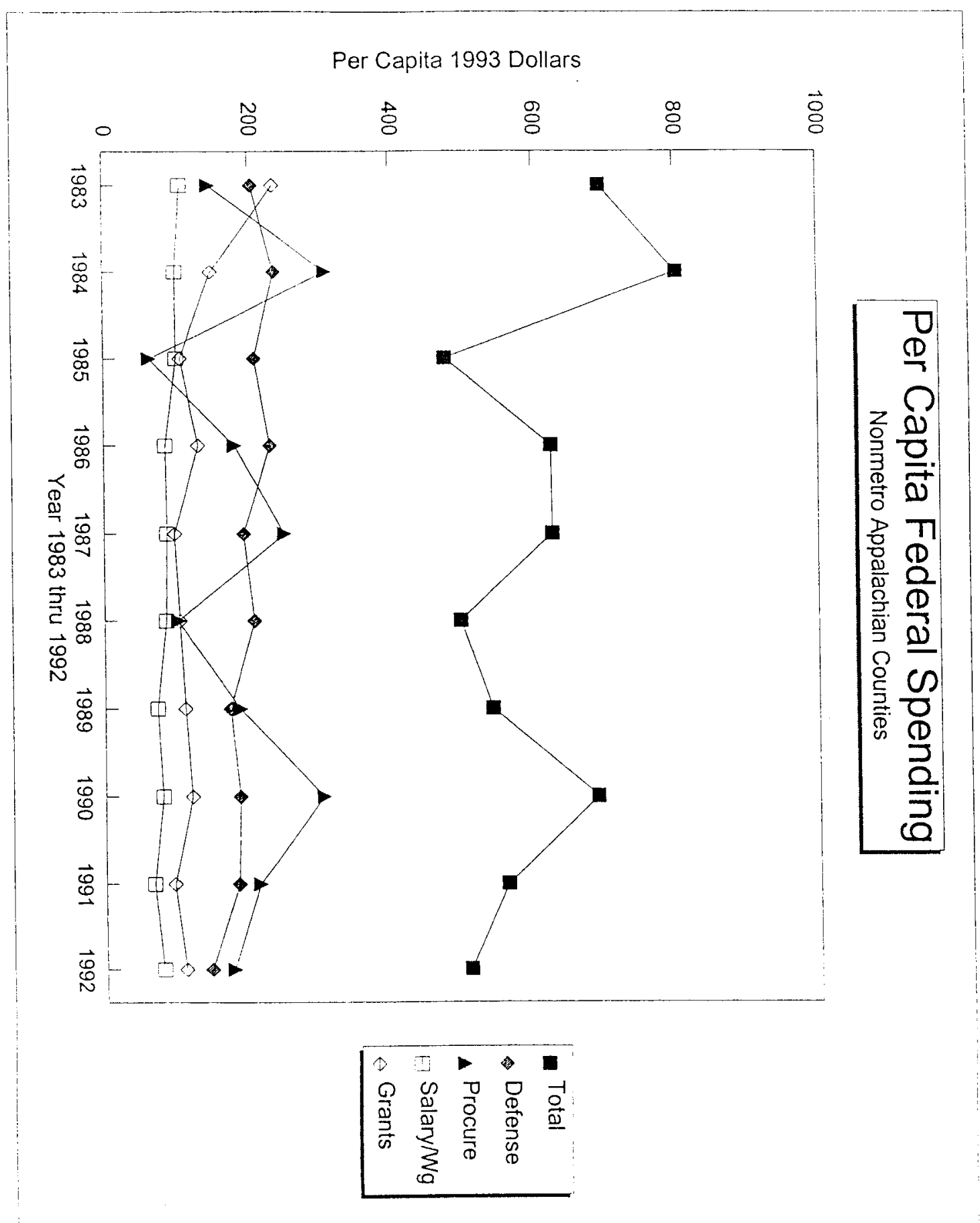

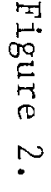




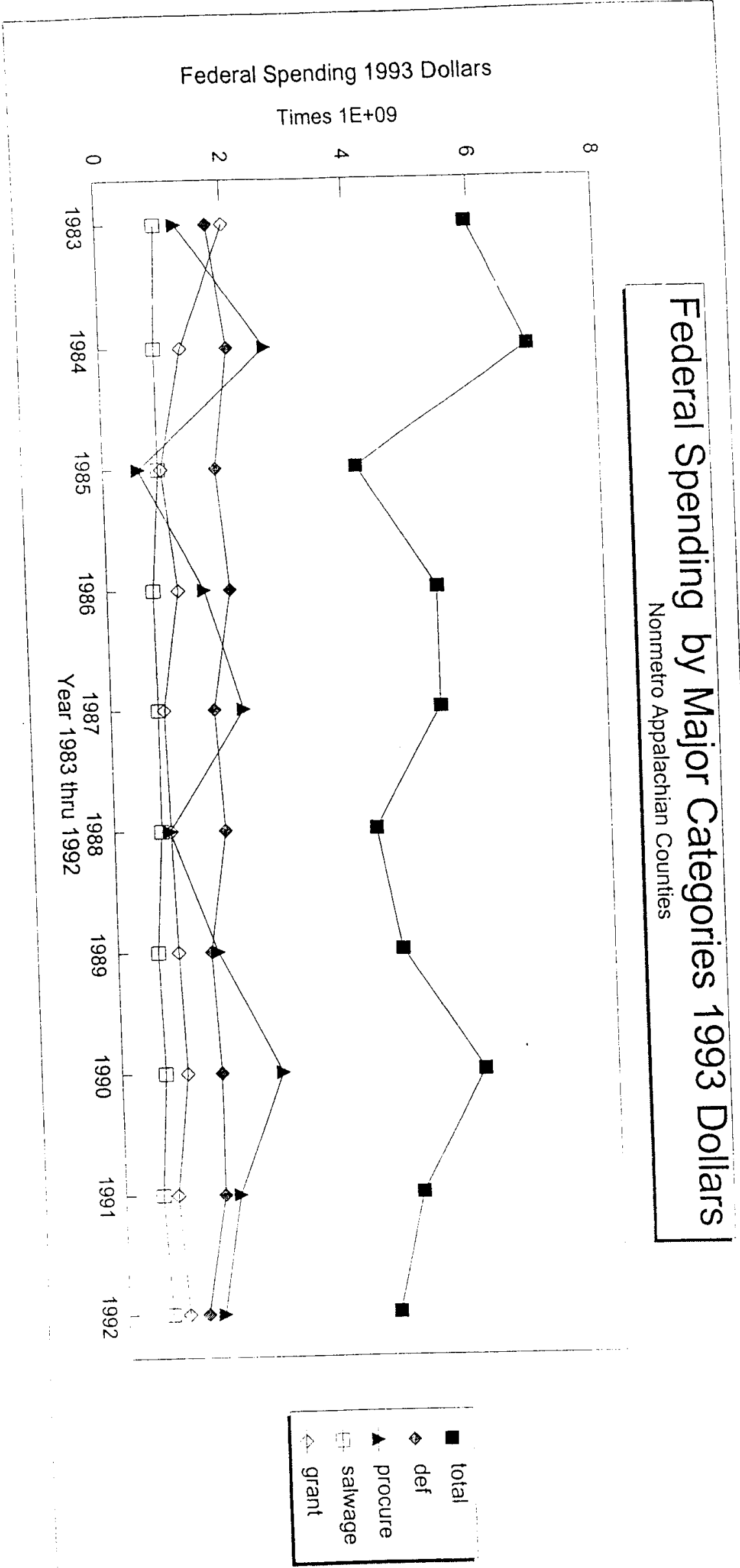




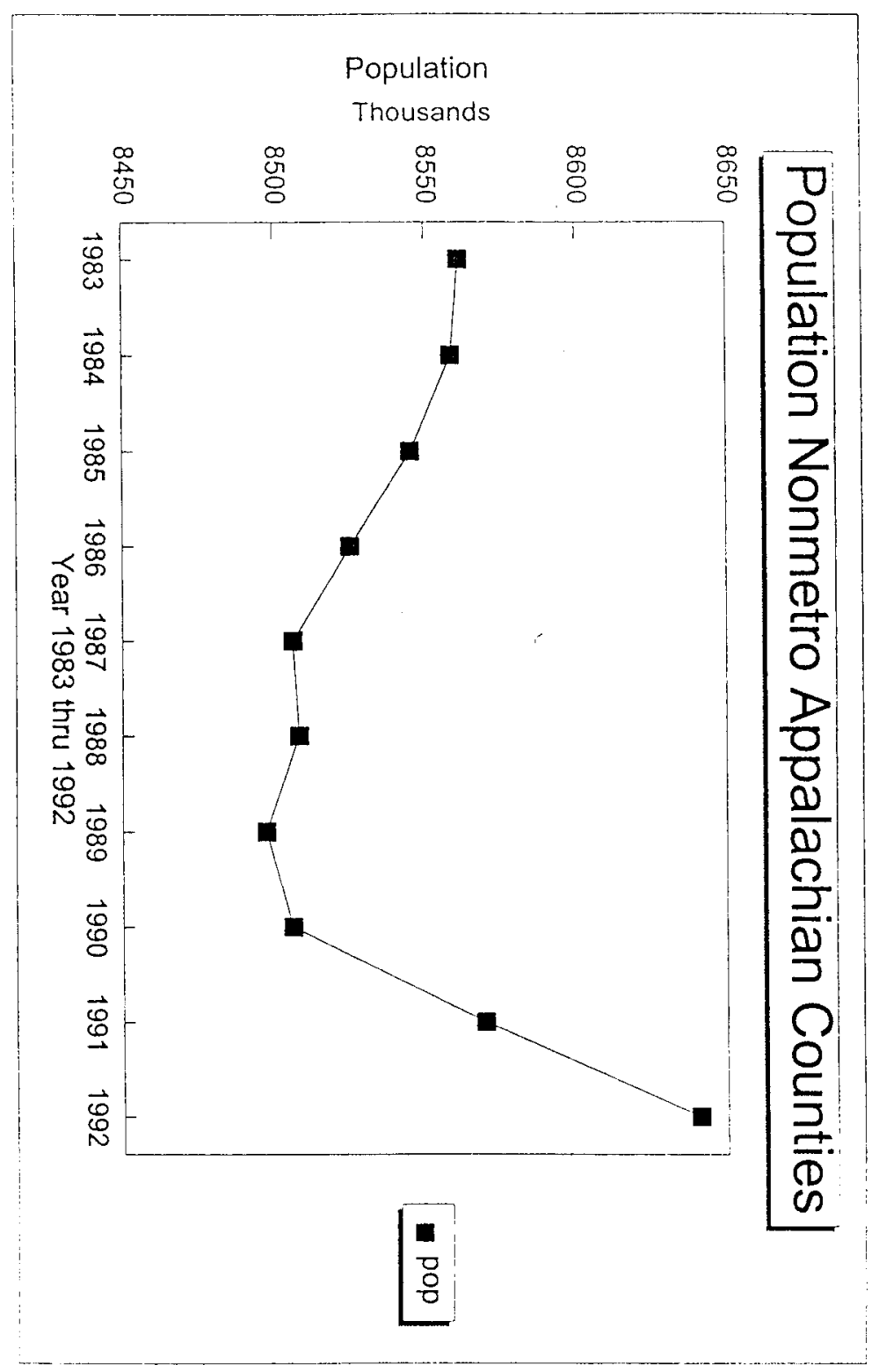

7
1
09
0
0
0
5
5 


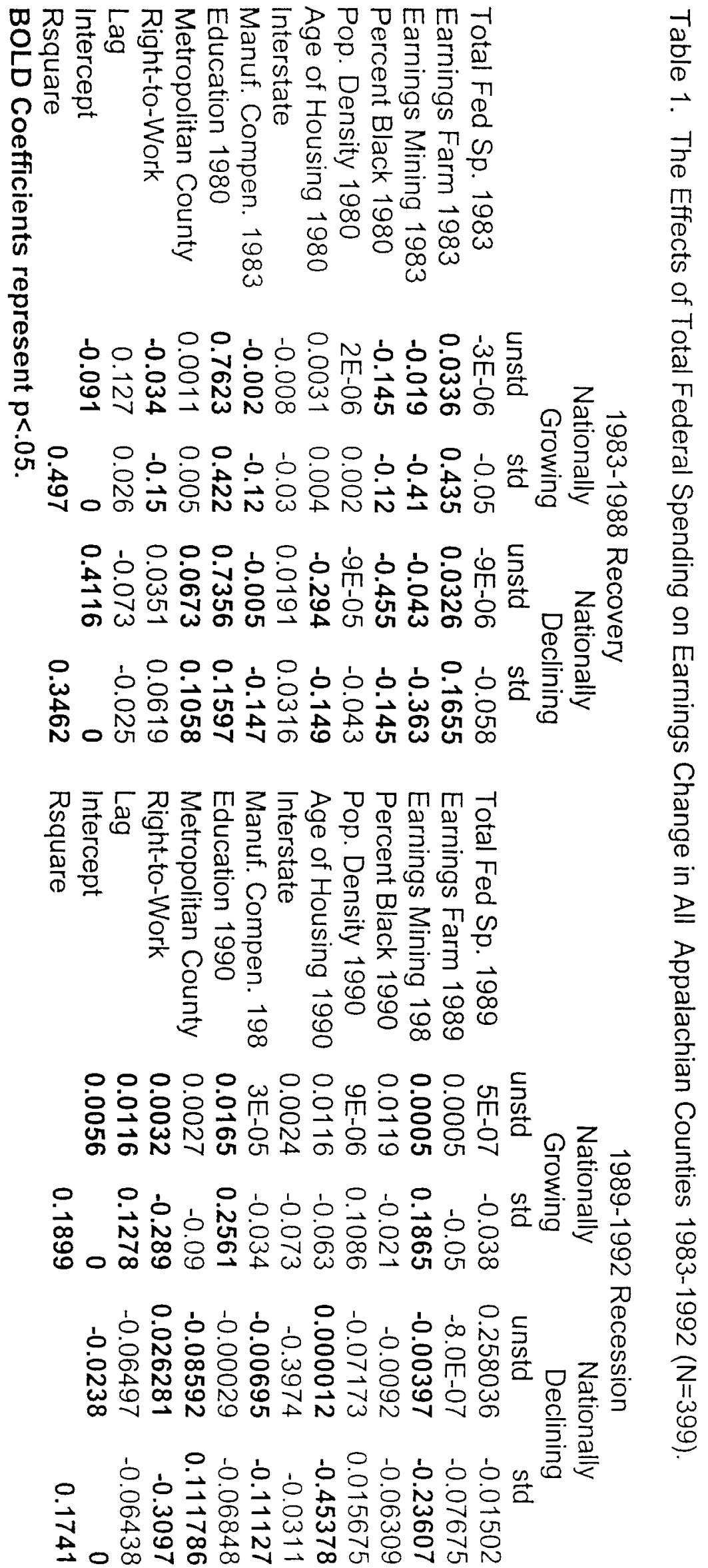


NOOOOOO

w

出

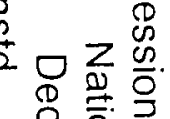

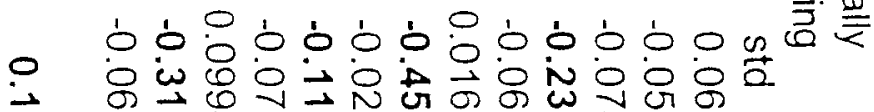

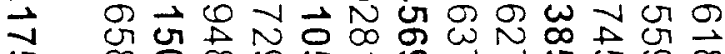

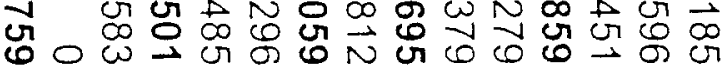




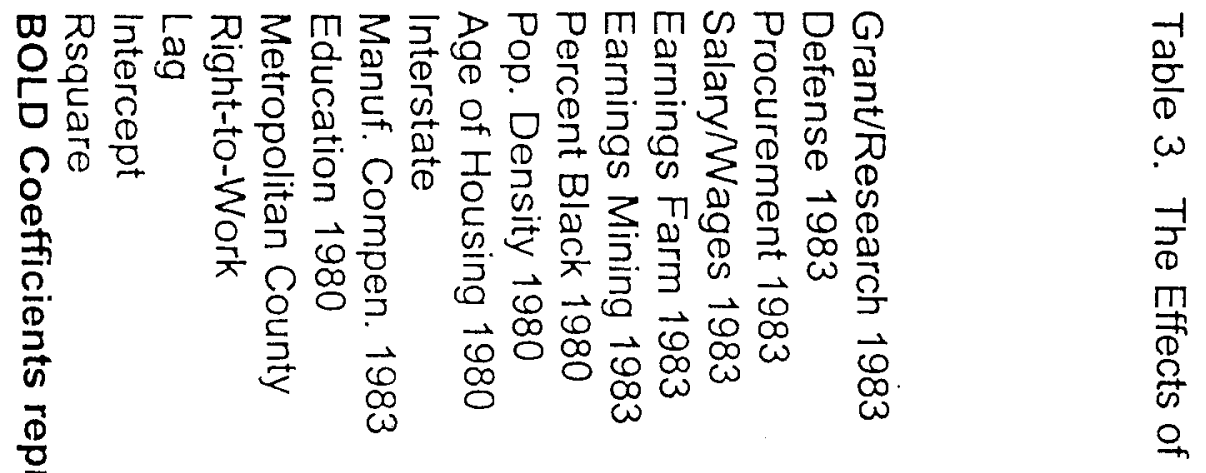

b

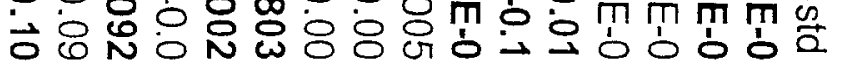

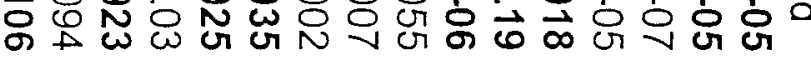

( )

9)

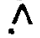

or

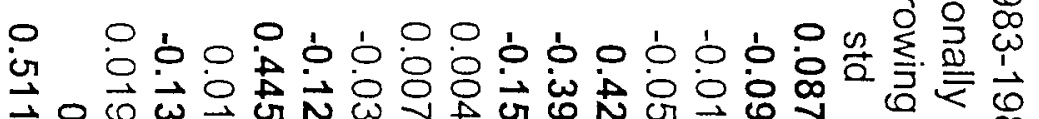

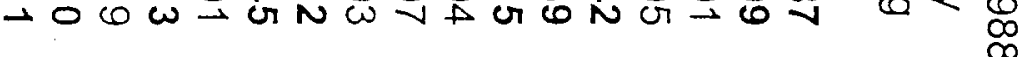

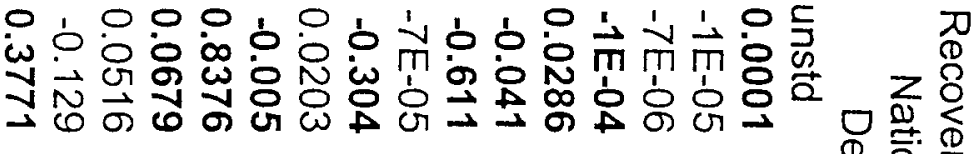

․

○

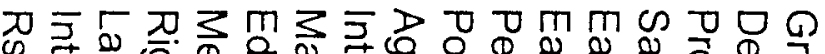

员

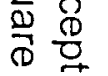

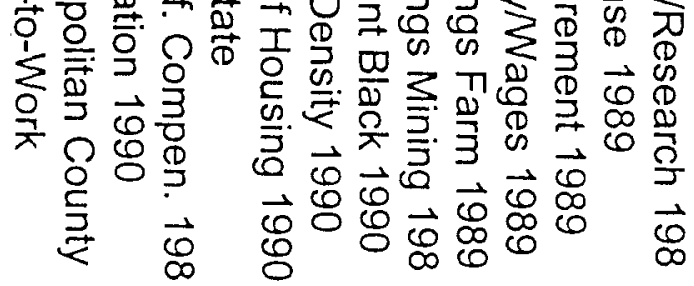

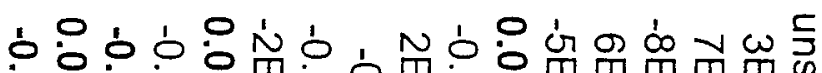

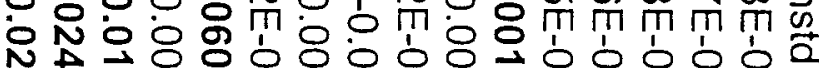

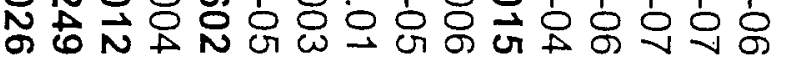

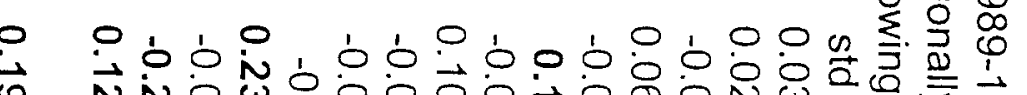

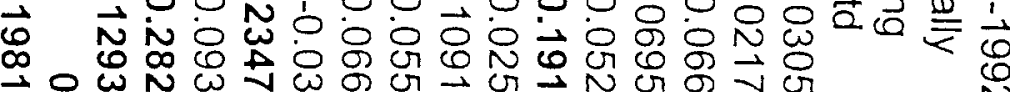

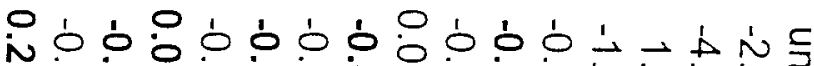

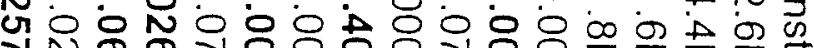

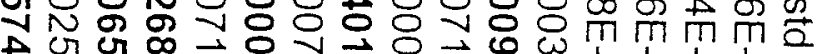

$\left.\rightarrow \infty \begin{array}{l}\infty \\ \rightarrow\end{array}\right)$

- b́lób

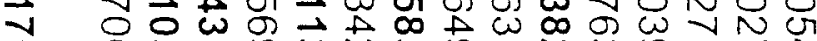

N $0 \omega \vec{\omega} \omega N \omega \omega \vec{N} \omega \omega \vec{N}$ 


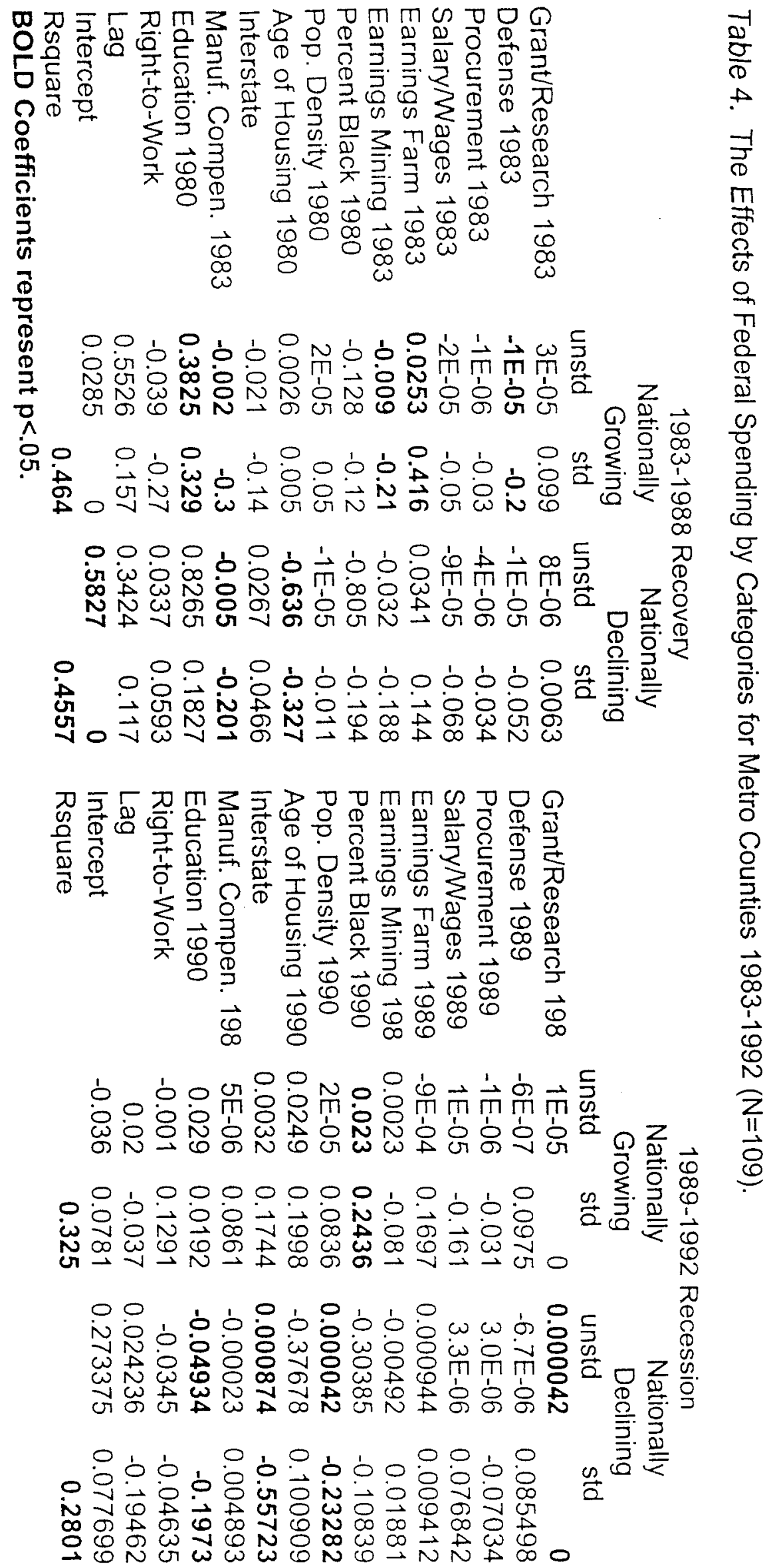




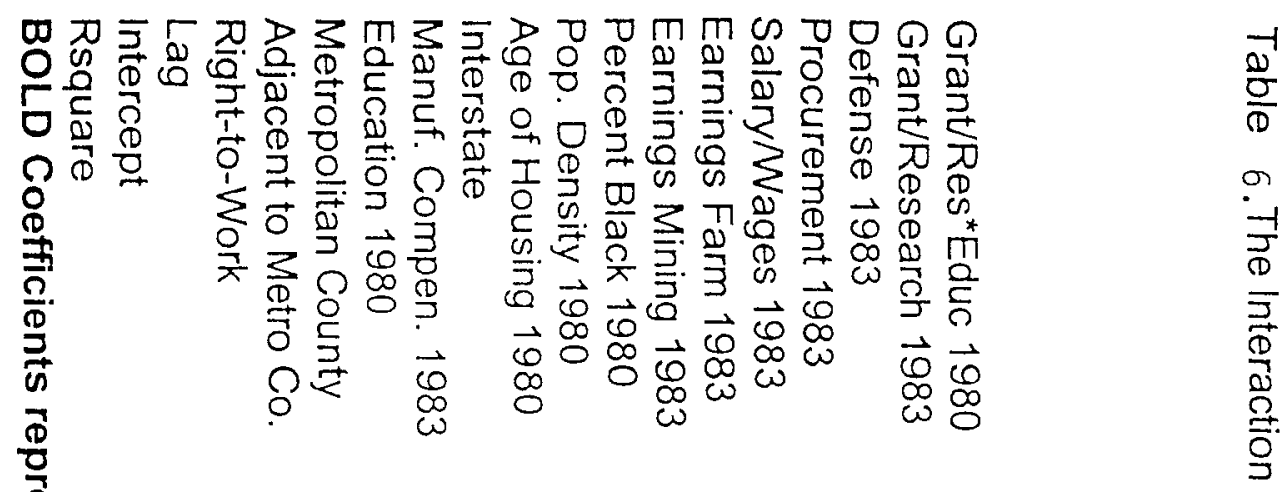

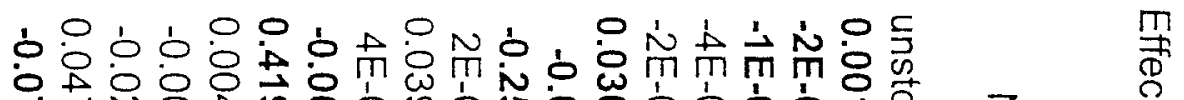

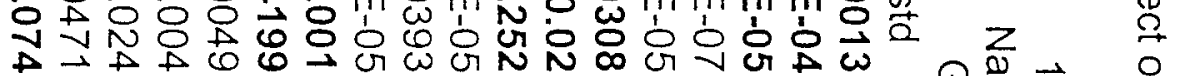

ర్గ

이 $0,10,000,0,1,0$,

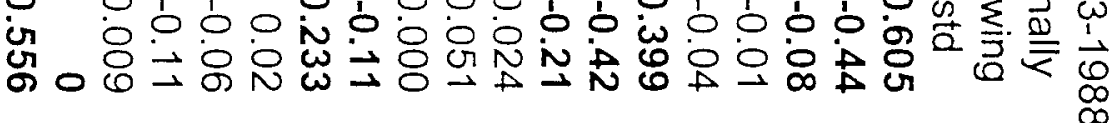

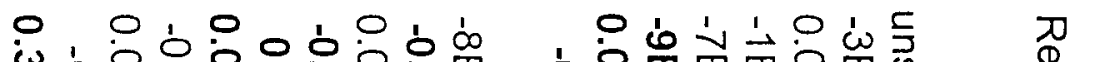
尔

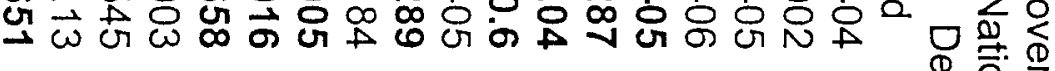

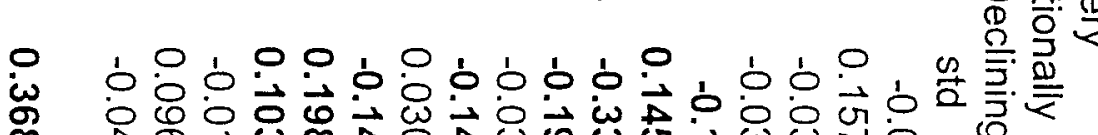

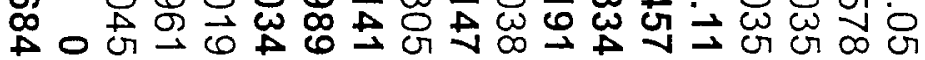

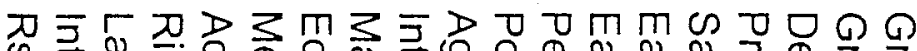

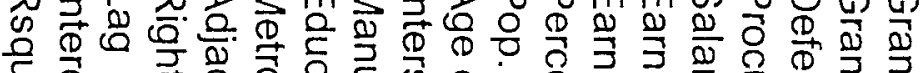

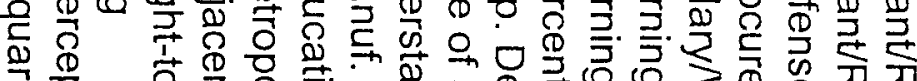

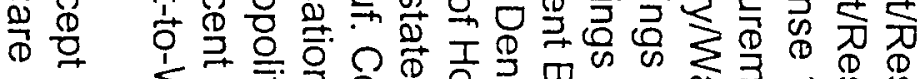

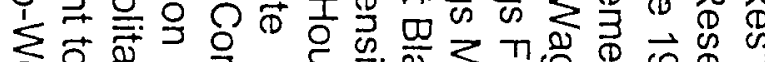

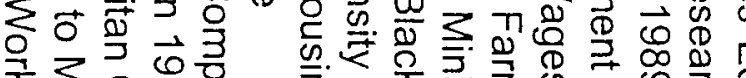

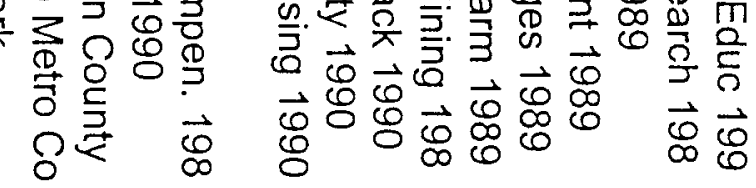

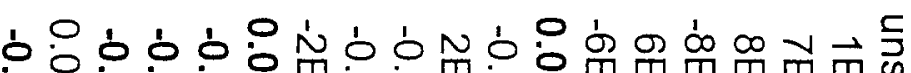

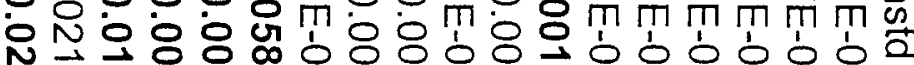

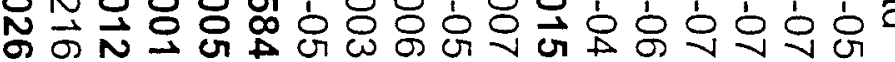

$Q$ Z

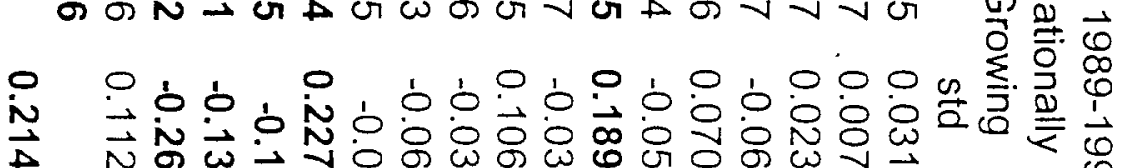

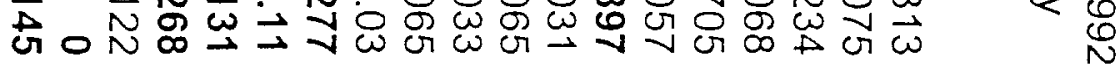

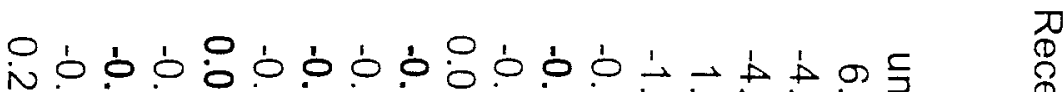

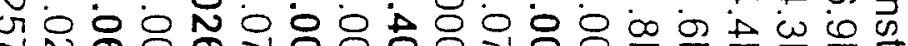

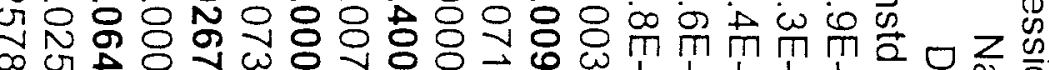

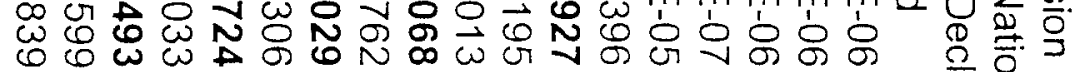

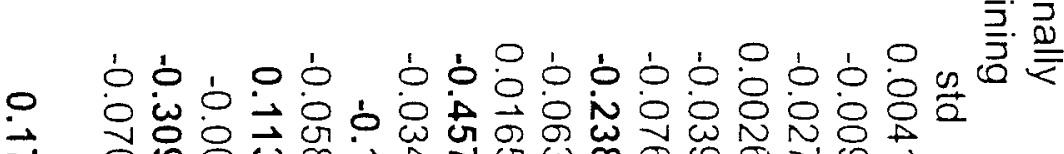

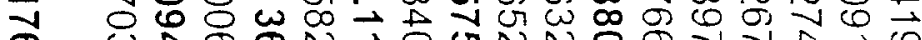

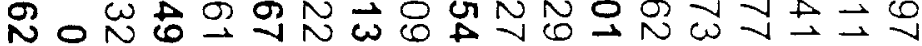


b

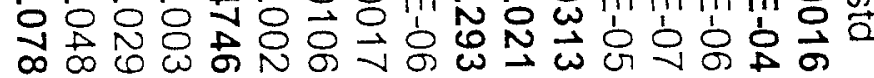

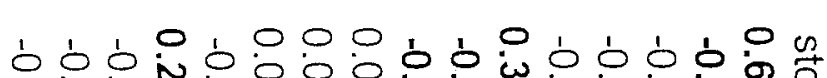
Q) $\stackrel{Z}{\stackrel{2}{\overline{0}} \overrightarrow{0}}$

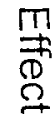

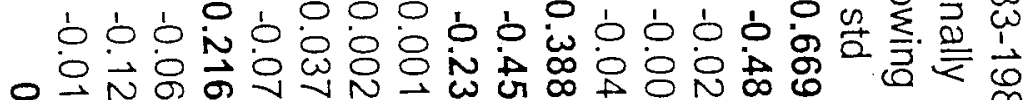

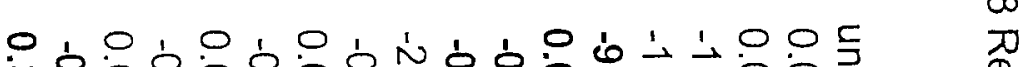
w

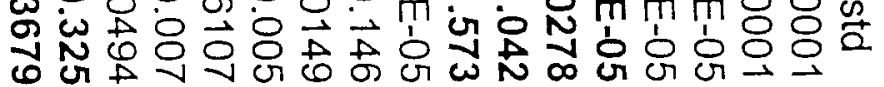

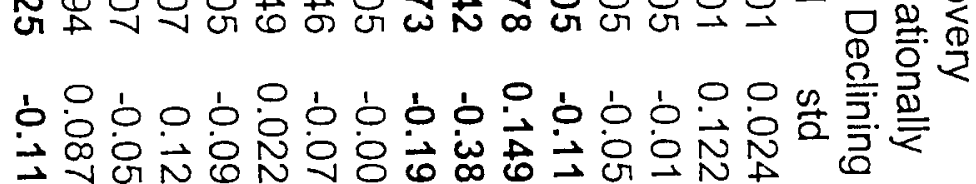
옥

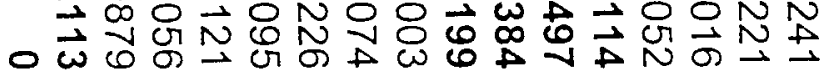

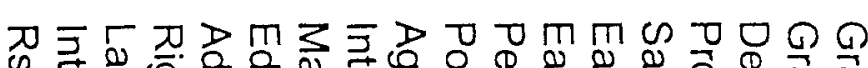

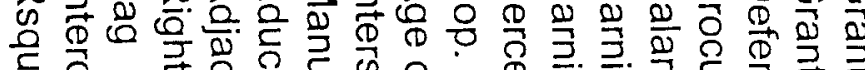

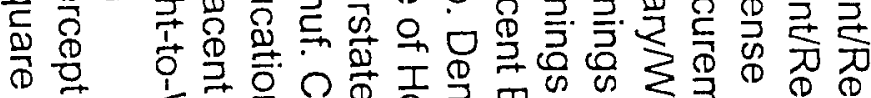

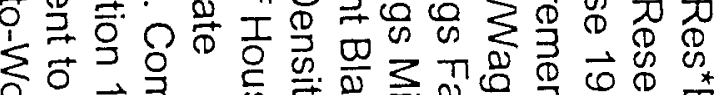

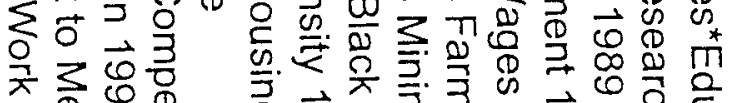

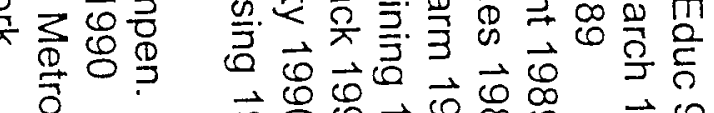

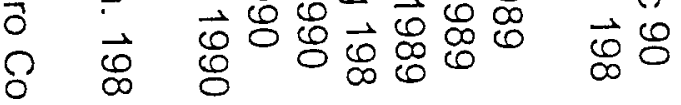

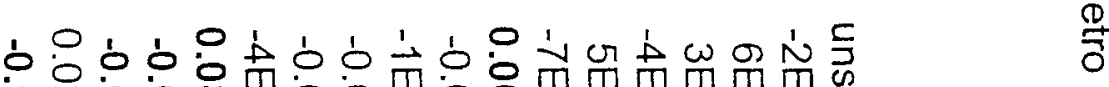

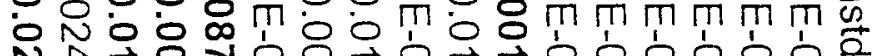

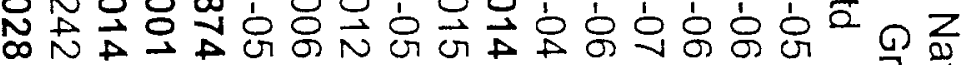

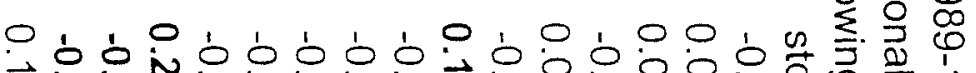

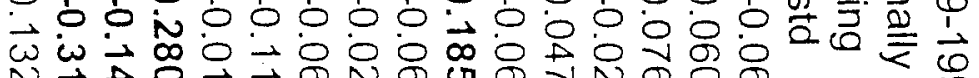

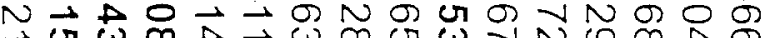

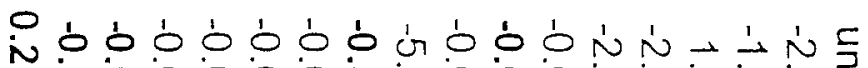

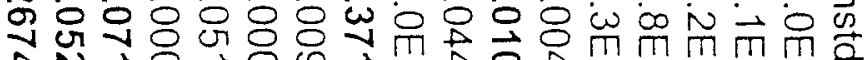

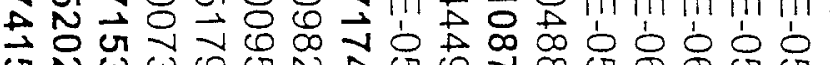
$\vec{r}$ 서

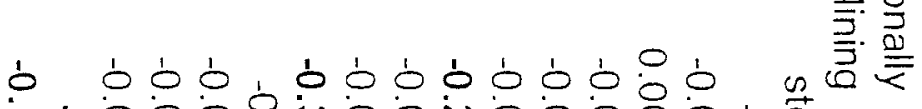

